\title{
Collective and Individual Factors in the Development of Creative Ideas in Art: The Perspective of Film Directors
}

\author{
ANDA LAKEE, LAURA BRUTĀNE, KETRISA PETKEVIČA \\ Latvian Academy of Culture, Ludzas 24, 1003 Rīga, Latvia \\ Email: anda.lake@lka.edu.lv
}

\begin{abstract}
The study focuses on the question if and how it is possible to balance the freedom of developing artist's individual creative idea and the societal demand for art defined in a concrete political context. The theoretical basis for the article is formed by research approaches grounded on sociology of creativity and social psychology. The object of the case study is film directors who had obtained funding for the production and dissemination of their films within the funding program 'Latvian Films for Latvia's Centenary' (2016-2018). The experience of film directors (N 16) was examined by using in-depth interviews and transcriptions analysed in accordance with qualitative methodology. The study identified two contingent levels of creativity inspiration - the individual and the societal or collective level. The authors identify several development models of the film directors' creative ideas, three of which are dominant: the independent outsider who stresses individual, seed-incident based creativity factors independent of the Latvian Centenary program; the independent idealist who stresses both individual and collective factors, independent of the Latvian Centenary program; the conforming patriot who stresses collective creativity factors that stem from the Latvian Centenary program. The view represented in the film directors' interviews has in common the assumption that the Latvian Centenary call had a positive influence on the film ideas, allowing the development of the artistic vision and conceptualising the framework for the expression of their ideas. The directors emphasise that there was no intentional configuration of the film creative ideas by formally adjusting them to the demand, thus circumventing the barriers of social field's gatekeepers. In many cases the idea had been developed long before the film idea call. Most directors admitted that the goal of the Centenary call appeared important to them both in terms of the state, and on the social and personal level.
\end{abstract}

Keywords: sociology of creativity, systems view of creativity, creative process, development of creative ideas in film art, creative ideas of film directors

\section{INTRODUCTION}

The study is based on the academic discussion of the factors in contemporary democratic societies that advance or hinder the development, realization and freedom of creative ideas in various spheres of art. The article focuses on conditions that may provoke conformity of artistic 
activity and the adjustment of creative idea to the values represented in the society and its dominant ideologies. The article also analyses the reflection of creative persons on the above issues. Numerous countries have public funding programs and instruments aiming at both supporting the development of various branches of national art, and ensuring that artistic products represent and communicate artistically national values. Doubtlessly such programs substantially expand the opportunities for the development of creative products. However, there are debates in the public sphere around the ambivalent impact of such programs on creative freedom and cultural diversity. One of the thematic strands of these discussions regards the question of whether it is possible to achieve a balance of the freedom of artistic ideas and the societal demand for art shaped by a specific political context. The question has scholarly topicality as well, substantiated by the idea of sociologists of creativity that 'creativity is not an inherent property of ideas, processes, and products, but the embodiment of an iterative relationship between the creator and their broader context' (Godart et al. 13: 2020). In addition, the particulars of the creative process are influenced by each specific artistic field (theatre, music, visual art, dance, film, etc.) and its special artistic language and essence, the availability of its products, as well as the unique historical context of artistic development in a given culture, state and territory. This in part explains why the study of artistic creation processes is dominated by case analyses of specific artistic processes and products; this does allow the accumulation of the material of empirical data, yet the extant theories can be elaborated only in the course of time-consuming study.

In the recent years, notable cultural phenomena that enriched the societal, political and cultural agenda in several Northern European countries (Estonia, Lithuania, Latvia, Finland, etc.) were the national Centenary Celebrations. These countries developed special budget instruments to fund activities related to this state event, and included targeted programs for culture and art. The Latvian Centenary spans the period from January 2017 to December 2021, with a total of more than 800 activities culminating in $2018 .{ }^{1}$ One of the most notable Centenary initiatives proposed by the Latvian National Film Centre was 'Latvian Films for Latvia's Centenary.' Its goal was to add to the body of Latvian films high quality, genre-diverse and societally important films addressing issues of Latvia's history, statehood and national identity. The program funding -8 million euros - was competitively awarded to 16 ideas of full-length films. The envisaged result was that the films should reach considerable audience and serve as an instrument of enhancing national belonging and identity. In the context of the study it is important that 1) this funding twice exceeded the previous annual budget of the Latvian National Film Centre and thus notably expanded the opportunities for film production; 2) targeted criteria addressing the ideological goals of the Latvian State Centenary were developed for awarding the funding by the Commission of film project selection (film projects had to fit several evaluation conditions, among others, the main subject of the film had to be cultural, societal, political or historical issues relevant for the Latvian society (Latvian National Film Centre); 3) the context for the development of the creative ideas of Latvian Centenary film projects, as well as the financial and moral responsibility of creative teams were influenced by the high-level saturation of the Latvian Centenary in terms of symbols, ideas and values. This unique cultural-historical situation was analysed as a research object in the research project 'The Art of Nationalism: Social Solidarity and Exclusion in Contemporary Latvia' funded by the Latvian

1 The Republic of Latvia was proclaimed on 18.11.1918.

2 https://www.lv100.lv/en/programme/lielnotikumi-en/ 
Council of Science and implemented by the researchers of the Latvian Academy of Culture. Within the frame of the project, researchers addressed a broad range of issues on the role of art in social solidarity and exclusion processes in society, as well as on the relationship between artists and the state in contemporary Latvia. The film industry was selected as the object of a case study. In its turn, the current article addresses the limitations and opportunities in the development of creative ideas by film directors. The authors assume that new knowledge on the process of the origin, development and change in the creative goals of film directors and the choices that impact the final version of the creative product (the film) is important not only for a deeper understanding of the creative process, but also for theoretic discussions on the genesis of artistic ideas, motivation of creative activity and authorship in specific cultures, timeframes and pivotal points of culture and history. The key research questions addressed in the article are as follows: 1) What individual and collective factors influence the development of the creative idea in film art? 2) How do artists (film directors) characterise the decisive factors of their creative ideas and reflect on the specific traits of the development of creative idea in the cases when the idea is being implemented as part of a state-subsidized program? The answers to the research questions were obtained by using both theoretical and empirical instruments of inquiry, where the empirical approach is grounded in the case study design.

The authors studied theoretical interpretations of creativity in sociology and social psychology, to understand the development traits of the creative idea and its determining conditions in art. The study took account of the specific nature of creative process in various branches of art, for instance, if it is individual (literature, visual art) or collective art (theatre, dance, film). We therefore analysed in more detail the sociological research tradition and characteristics of creative process in film art. The case study addressed the opinion and experiences of those film directors who received funds for film production from the program 'Latvian Films for Latvia's Centenary'. While the methodological core principles of case studies do not permit generalization, the scope of empirical material allows making conclusions about the interaction of the context, collective and societal values, for example, the creative idea competition requirements, and expectations of policy makers, competition commission experts and the public, with the individual creative idea of film directors. Although the study had to take into account the conceptual elusiveness of the creative process (Reckwitz 2017) and other epistemological limitations, sociologists have recently become more interested in the social context of creativity, the nature of creative processes and the way artworks acquire a specific creative value. Scholars admit that the goal of creativity studies is 'not to try to force creative processes into certain models or to propose final recipes, but $\langle\ldots\rangle$ to gain a more nuanced understanding of practitioners' choices and production processes... It is, however, crucial as researchers to explore the processes of producing art to see what can be learned from the actual practice of making the dreams of films come alive' (Godart et al. 2020: 7).

\section{CONCEPTUALIZATION TRADITION OF CREATIVITY AND CREATIVE PROCESS IN SOCIAL SCIENCES AND SOCIOLOGY}

Philosophers and thinkers from other disciplines have long tried to define the concept of creativity, to develop a systematic and scholarly view of creative persons, perceived either as geniuses or the chosen ones, or individuals endowed with special creative abilities. In social sciences, various theoretisations have been given by sociologists, psychologists, economists, representatives of communication science and others. In sociology, 'creativity' and its related 
phenomena are not a 'typical' research object. Although creativity is present in theories of innovation, development and social change, researchers (Reckwitz 2017; Watts Miller 2017) consider the concept deprived of full recognition in sociological theory. This has several reasons, an important one being that creativity has been long perceived as the research object more suitable for the epistemological tools of 'neighbour disciplines' - psychology and anthropology. However, in the recent decades quite a radical turn has happened in sociology, as new and persuasive in-depth theoretical and empirical studies on creativity have been conducted and new knowledge acquired. Currently there is an ongoing debate on the concept of creativity, mostly on the most precise way to systematize ideas of creativity in general society and how to define its manifestations in different cultural practices, including arts. Moreover, the contemporary traits of societal development and transformation point to the emergence of a special sub-branch of sociology - sociology of creativity. In the frame of this article we will not offer a full analysis of research strands in the sociology of creativity; instead we will focus on the theoretical explanations of creativity that have an epistemological potential to provide an analytical basis for the empirical study of film directors' opinions and experiences. One of the core conditions of empirical research is developing a definition of creative process that could serve as a basis for a methodologically credible and comparable operational definition for the empirical study of specific manifestations of creativity. We have already noted the elusiveness of the concept of creativity, which has provoked academic discussion on related concepts and synonyms, such as creative imagination, inventiveness and others. These discussions explicate expressions of creativity by a broader societal context and cultural practices, but only in part do they uncover the specific traits of artistic creativity. An especially significant contribution to the development of sociology of creativity is the systematization of a prior scholarly work conducted by F. Godart, S. Seong and D. Phillips (Godart et al. 2020). The scholars have identified three core assumptions that characterise the scholarly approaches in sociological analysis of creativity. Firstly, they note approaches that interpret creativity in a broad way, assuming that creativity exists not only in the form of high art but also in everyday activities. Creativity here is defined as a configuration of cultural and material elements. Secondly, they emphasise that it is important to explore the balance of purposeful activity and chance in creative processes. These approaches accentuate that creativity is intentional in the sense that it is not the result of chance events or pure randomness occurring beyond the reach of social actions. Concurrently it is noted that this is not to imply a total absence of randomness in the creative process. Thirdly, Godart et al. note that in studying creativity one has to take into account the interaction between the creative person/s and the audience, grounded in the assumption that creativity is located at the intersection of production and consumption - the two sides of the creative process competing for what should be seen as unexpected. Summarising the characteristic traits of these three approaches Godart et al. provide their own definition in the latter tradition and define creativity as an intentional configuration of material and cultural elements that is unexpected for a given audience (Godart et al. 2020: 7). This definition emphasises a significant dimension of creativity, which in empirical research requires identifying the elements that may promote cultural and material configurations that are intentional and at the same time unexpected.

The analysis of prior research unfolds the dominant attempts to define creativity, as well as allows identifying two relative levels of creativity - individual and societal or collective. This distinction, we believe, is particularly useful in analysing the factors affecting the development of the creative idea, which in our study are examined through in-depth interviews with creative persons (directors of Latvian Centenary program films). 


\section{CREATIVITY IN THE SOCIETY AND ITS COLLECTIVE NATURE}

In sociology, in accordance with its specific disciplinary character, creativity is predominantly viewed as a general trait of societal processes. In addition, most studies emphasise that creativity in sociology is collective in the sense that social structures, networks and interactions, as well as history and other elements of the social context form a framework for the development of creative ideas. Every creative act is embedded in larger structures, institutions and contexts that enable or constrain creative configurations (Weber 2005). Based on the assumption that one cannot study creativity by isolating individuals and their creative activity from the social and historical environment, that creativity does not exist in a vacuum, a theory of creativity was developed by the Hungarian-American professor of psychology and management M. Csikszentmihalyi (Csikszentmihalyi 1999: 315). Explaining his systems model, Csikszentmihalyi has described how his early studies of the creative process focused on individual thinking, emotions and motivation and yet that approach did not allow explaining significant aspects of the creative process (Burns et al. 2014). According to Csikszentmihalyi, creativity is the result of an interplay between three systems, which can be structured in a systems view of creativity: Society (Field) - Culture (Domain) - Personal Background (Individual) (Csikszentmihalyi 2014: 47). According to this approach, the creative process is determined by dynamic relations of circular causality, where the three systems are both influenced by and influence each other. In this model, creativity is not an attribute of individuals, but a social system. Society or the social field organises the cultural domain and it includes all individuals who function as gatekeepers, deciding which idea or product gets included in the creative domain (Csikszentmihalyi 1999: 315). The gatekeepers may be patrons of art, curators, art critics and other persons who are responsible for the inclusion of products in the cultural domain. The individual is viewed as the third element in the general system. In accordance with this theory, that entry point of creativity may be anywhere. It may start with the individual, the social field, or the cultural domain. Analysing the development and realization of creative ideas of film directors within the framework of the funding program 'Latvian Films for Latvia's Centenary', it is essential to adopt the approach in which individual and collective impulses for creativity are viewed in a dynamic circular interaction, paying particular attention to identifying the gatekeepers in this process.

\section{THE CREATIVE PROCESS IN ART AND ITS INDIVIDUAL TRAITS}

Researchers who analyse the creative process in art have developed somewhat different approaches. While in Csikszentmihalyi's approach to creativity there are attempts to develop a broader, holistic understanding of creative activity, researchers of the creative process in art focus their attention on the creative person as an individual - on the genesis of the creative idea in artist's activity, on their individual traits - talent, gifts and others. In trying to conceptualise the creative process in art, some of the researchers have developed a structuring of the creative process in phases, to illuminate the internal logic of the process. Many scholars - psychologists, social psychologists, psychiatrists, cognitive scientists, neuroscientists, anthropologists and now also sociologists - have taken up as a special challenge the task of rationalising the processes producing unexpected and astonishing, even genius manifestations of creativity in art, to capture the technique of idea generation (Young 1975 etc.). Many scholars in their theories have developed and continue developing the model of four steps created almost a hundred years ago, which is considered a pioneering model of the stages of 
creativity. Its author is Graham Wallas, co-founder of the London School of Economics. Wallas wrote 'The Art of Thought' (Wallas 1926), a theory that marks the four stages of the creative process. Currently the printed versions of the above book are a bibliographic rarity, however the model of the four stages of the creative process - preparation, incubation, illumination and verification - has since been developed, elaborated and modified (Sadler-Smith 2015: 342). Drawing on contemporary processes in creative industries and arts, scholars have developed increasingly numerous models of the creative process and its specific stages (Lubart 2001: 297). Characterisation of these models is complex and goes beyond the scope of this article, however, for our study of special importance are the approaches that attempt to identify the 'birth' of creative ideas, their starting and inspiration points. The goal is to identify the beginnings and the film development idea and its configurations as influenced by the objectives and funding of the Latvian Centenary film competition. We have identified the first addition to the existing models, a start of the creative process - the concept of 'seed incident'. It is introduced by Ch. L. Doyle, who analysed the creative process of writers (Doyle 1998: 29). The concept of seed incident in various studies has been treated as a source of inspiration for the start of creative activity, or its beginning point (Lubart 2001: 298). Empirical observation - both media interviews and scholarly interviews - attests that not only writers, but film and theatre directors, composers, painters and poets point to various unexpected inspirations for the creative process, which have traits of a seed incident. In our opinion, in the context of film industry, it is important to identify precisely that initial motivation or inspiration which has promoted the development of the work of art - in this case, film - and implementation in real film production. This would allow identifying a clearer genesis of the creative idea, the prospects and hindrances of its further development in the context of the concrete cultural and social field, including the societal demand and the actions of gatekeepers.

To study why and how an artist decides to focus on a concrete idea or subject, approaches have been developed where art and creative processes are viewed as problem identification and solving. The creative idea is viewed as the second stage of the creative process, where the first one is understanding of a problem (Redvall 2012: 63). Within the realm of cognitive studies of creative processes, creativity has often been regarded as a form of problem solving. A problem can be defined as 'a situation with a goal and a hindrance' (Runco 2007: 14). If one has a clear-cut problem, one can, of course, move on to problem solving immediately, but in many artistic processes, choosing the problem to actually solve will often be central to the process. In our view, the creative process as a form of problem solving has to be treated in integration with the analysis of instances of the seed incident, as they provoke the artist to examine and uncover more of the identified problem. They are the starting point of all art process, which the artist may not even be aware of initially. We conclude that the artistic creative process is largely determined by individual traits of the creative person. In artists' activity, her prior experience of artistic activity and life experiences in general have a special importance (Mace et al. 2002: 182), transforming greatly the external influences, i.e. the contextual collective factors influencing creativity.

\section{CREATIVITY IN FILM ART}

The empirical study and data analysis of the creative ideas of film directors developing films funded by the Latvian Centenary program took into account the specific role in society enjoyed by the film art and its creative products. In sociology of film, inter alia, films are viewed as a means for conveying a message, meanings of the internal, social and cultural world of 
the individuals and society (Wejbert-Wąsiewicz 2020: 94). The Brazilian sociologist J. Donascimento points out that analysis of films allows analysing society, as films themselves are created based on analysis of society (Donascimento 2019: 22). The clear-cut social role of film art adds another layer of importance to the need to test the film creative idea development processes, its turning into a script, a film, and its dissemination in a specific society for a specific audience.

\section{DETERMINING FACTORS OF THE DEVELOPMENT OF CREATIVE IDEA OF LATVIAN CENTE- NARY FILM DIRECTORS: THE INDIVIDUAL AND THE COLLECTIVE DIMENSIONS}

Theoretical studies of creativity allowed us to identify individual and collective traits of the process and to develop an analytical model for empirical study. The study and analysis of the experiences and opinions of Latvian Centenary film directors was conducted according to the core principles of qualitative methodology and using the case study design. We carried out 15 in-depth semi-structured interviews with the film directors of the Latvian Centenary film competition who represented 14 of 16 Latvian Centenary films, at the time when the films had already been shown to the audience (summer of 2021). The interview guidelines had questions in five thematic strands: the development of film's creative idea; artist's independence; creative freedom and self-censorship; the state and artist's relationship; artist, artwork and society; the experience of the Latvian Centenary film idea competition. The experiences of film directors are structured by the reflection by artists of different generations, genders, professional experience and various art genres (feature films, documentaries, popular science films, and animation). The directors reflected on the genesis of the film idea and its development, up until submitting it to the Latvian Centenary film idea competition and up to the time when in accordance with the selection Commission (industry experts and policy-makers) it acquired funding for its production. To assess the film idea development process and the role of selection criteria and Latvian Centenary in it, the experiences of the directors were categorized as follows: the material was included in a formalized, abstract timeline: 1) the creative idea was developed prior to the announcement of the call for proposals; 2) the creative idea was developed after the call, when preparing the film proposal; 3 ) there were or were no adjustments in shooting the film. The interview data were also analysed by thematic grouping of directors' views, focusing on the following: 1) the role of individual factors; 2) the role of collective factors, including the call's goals and selection criteria; 3 ) a link between individual and collective factors in the development of the creative idea.

\section{CONCLUSIONS}

The data analysis allowed the formulation of several models of developing the film directors' creative ideas, with three dominant ones:

The independent outsider: emphasised factors that were individual, seed incident-related and independent of the Latvian Centenary film call;

The independent idealist: emphasised factors which were both individual and collective but independent of the Latvian Centenary film call;

The conforming patriot: emphasised collective and the Latvian Centenary call-related factors.

The common trait in all directors' opinions is the desire (emphasised in different contexts of the interviews) to develop the idea of a film which is indisputably unique. The differences are present within each of the models. In the first model, the film idea had already 
been developed before the Centenary call, sometimes even several years before. In these cases, the directors stress the factors in creative ideas development which are individual, deeply subjective and rooted in personal values, deep emotional experience and the need for creative self-expression. The first impulse for selecting the idea is explained by chance coincidences, sudden inspiration and a special event, including another creative imagination-stimulating cultural or art event that one of the informants called 'the click'. In this scenario, the seed incident acquires great importance. These directors considered the call for the proposals to be a financial and creative opportunity for the development of the creative idea, a lucky coincidence, where the Latvian Centenary background, the call guidelines and expert decisions are perceived as a supportive and beneficial collective context, and not a determining factor for the development of the idea. The second model also characterises situations when the idea had been developed before the call for film proposals, yet the origin of the idea is presented in a rational way, citing the personal need to use artistic language to talk about an important societal problem, a fact whose representation in the film form is perceived as especially significant in the concrete social political, economic or cultural context. This process of idea origination and development is usually accompanied by collecting materials, research, studies of historical memory and other sources. It is characterised by a dynamic synergy of personal interest and the social significance of the subject. In addition, the directors admit a high loyalty of the social field gatekeepers for their ideas.

The third model includes the cases in which the creative idea is developed purposefully acknowledging the need to represent the nation and the state by this artwork and informants admit that the film most probably would not have been produced if not for the Latvian Centenary. Moreover, they stress that the Latvian Centenary as a cultural-historical event added extra value, specified the artistic vision and the ideological, socially meaningful frame for the creative idea.

The authors conclude that the opinions represented in the film directors' interviews have in common the fact that the creative idea - the film proposal - was not intentionally configured by formally subordinating the film idea to circumvent the gatekeepers of the social field (the call evaluation committee and the potential conformity to audience expectations). The directors stressed that the Latvian centenary call as a collective need influenced the film ideas in a positive way, allowing the development of the artistic vision and conceptualising the framework for the expression of artistic ideas. Most artists stressed that the goal of the Centenary call seemed to them important both politically, socially and personally. The target program of art funding grounded in the values of national culture and dominant political ideology, dedicated to a unique cultural artifact (Latvian State Centenary) is not perceived as a threat to the creative choices of the film directors. Simultaneously, a discussion and further research question remains - if and under what conditions a systematic use of similar funding tools would cultivate barrier risks of the social field and threats to a diverse cultural domain.

\section{ACKNOWLEDGEMENTS}

This research is funded by the Latvian Council of Science, Project 'The Art of Nationalism: Social Solidarity and Exclusion in Contemporary Latvia', Project No. lzp-2020/2-0118. 


\section{References}

1. Burns, T. R.; Machado, N. 2014. 'The Sociology of Creativity: A Sociological Systems Framework to Identify and Explain Social Mechanisms of Creativity and Innovative Developments', Working Papers CIES/ IUL 196: 1-38.

2. Csikszentmihalyi, M. 2014. The Systems Model of Creativity: The Collected Works of Mihaly Csikszentmihalyi. Claremont: Springer.

3. Csikszentmihalyi, M. 1999. 'Implications of a Systems Perspective for the Study of Creativity', in Handbook of Creativity, ed. R. J. Sternberg. Cambridge: Cambridge University Press, 313-338.

4. Doyle, C. L. 1998. 'The Writer Tells: The Creative Process in the Writing of Literary Fiction', Creativity Research Journal 11(1): 29-37.

5. Godart, F.; Seong, S.; Phillips, D. 2020. 'The Sociology of Creativity: Elements, Structures, and Audiences', Annual Review of Sociology 46(1): 14.1-14.22.

6. Latvian Academy of Culture. The Art of Nationalism: Social Solidarity and Exclusion in Contemporary Latvia. Available at: https://lka.edu.lv/en/research/research-projects/fundamental-and-applied-research-projects/art-nationalism-social-solidarity-and-exclusion-contemporary-lat/ (accessed 22.09.2021).

7. Lubart, T. I. 2001. 'Models of the Creative Process: Past, Present and Future', Creativity Research Journal 13(3-4): 295-308.

8. LV100. Major Projects of Centenary. Available at: https://www.lv100.lv/en/programme/lielnotikumi-en/ (accessed 22.09.2021).

9. Mace, M. A.; Ward, T. 2002. 'Modeling the Creative Process: A Grounded Theory Analysis of Creativity in the Domain of Art Making, Creativity Research Journal 14(2): 179-192.

10. National Film Centre of Latvia. Annual State Support. Available at: https://www.nkc.gov.lv/en/annual-state-support (accessed 22.09.2021).

11. National Film Centre of Latvia. Latvijas filmas Latvijas simtgadei 2015. gada filmu projektu ražošanas uzsākšanas konkurss. Available at: https://www.nkc.gov.lv/lv/jaunums/latvijas-filmas-latvijas-simtgadei-2015-gada-filmu-projektu-razosanas-uzsaksanas-konkurss (accessed 22.09.2021).

12. Redvall, E. N. 2012. 'A Systems View of Film-making as a Creative Practice', Northern Lights: Film \& Media Studies Yearbook 10(1): 57-73.

13. Runco, M. A. 2007. Creativity: Theories and Themes: Research, Development, and Practice. Burlington, MA: Elsevier Academic Press.

14. Sadler-Smith, E. 2015. 'Wallas' Four-Stage Model of the Creative Process: More Than Meets the Eye?', Creativity Research Journal 27(4): 342-352.

15. Wallas, G. 1926. The Art of Thought. London: J. Cape.

16. Watts Miller, W. 2017. 'Creativity: A Key Durkheimian Concern and Problematic', Revue Européenne des Sciences Sociales. European Journal of Social Sciences 55(2): 17-40.

17. Wejbert-Wąsiewicz, E. 2020. 'Film and Cinema as a Subject of Sociological Study. Between Tradition and the Present', Acta Universitatis Lodziensis. Folia Sociologica 73: 89-110.

18. Young, J. W.; Reinhard, K. 1975. A Technique for Producing Ideas. Lincolnwood: NTC Business Books. 
ANDA LAĶE, LAURA BRUTĀNE, KETRISA PETKEVIČA

\title{
Kolektyviniai ir individualūs kūrybinių idèjų raidos veiksniai: kino režisierių nuomonè
}

\begin{abstract}
Santrauka
Tyrimas siekia atsakyti ị klausimą, ar ir kaip įmanoma subalansuoti menininkų individualių kūrybinių idejjų raidos laisvę su konkrečiame politiniame kontekste kuriamo meno visuomenine paklausa. Straipsnis paremtas kūrybiškumo sociologijos ir socialinès psichologijos teorinėmis prieigomis. Atvejų studijos objektu pasirinkti tie kino režisieriai, kurių filmams kurti ir platinti skirtas finansavimas pagal programą „Latvijos filmai Latvijos šimtmečiui“ (2016-2018). Režisierių patirtis (N16) tirta taikant giluminio interviu metodą, transkripcijos analizuojamos remiantis kokybinès metodologijos principais.
\end{abstract}

Kūrybiškumo sampratos tyrimo tradicijos analizė leidžia išskirti du sąlyginius kūrybinio įkvejpimo lygmenis - individualų ir visuomenini arba kolektyvinị. Remiantis tiriamais atvejais, darytina išvada, kad galima išskirti keletą kūrybinių idejjų raidos modelių, iš kurių dominuoja trys: nepriklausomas autsaideris, kuris pabrěžia individualius, impulsyvius (seed incidents), nuo LV šimtmečio programos konkurso nepriklausomus kūrybinius veiksnius; nepriklausomas idealistas, akcentuojantis tiek individualius, tiek ir visuomeninius, tačiau nuo LV šimtmečio programos konkurso nepriklausomus kūrybiškumo veiksnius; konformistas patriotas, išskiriantis kolektyvinius veiksnius, kylančius iš LV šimtmečio programos konkurso nuostatų. Kino režisierių nuomone, Latvijos šimtmečio konkursas kaip kolektyvinis poreikis turejjo teigiamos įtakos kino idejų raidai, leisdamas plètoti meninę viziją ir konceptualizuoti kino menininkų kūrybinių idèjų ribas. Pabrèžiama, kad kūrybinè filmo idejja sąmoningai nebuvo konfigūruojama, o tik formaliai pritaikoma visuomenès poreikiams, siekiant apeiti socialinio lauko sergètojų barjerus. Be to, daugeliu atvejų ideja buvo išplètota jau gerokai iki konkurso pradžios. Daugelis režisierių pripažino, kad šimtmečio konkurso tikslas jiems atrodè svarbus tiek nacionaliniu, tiek visuomeniniu, tiek asmeniniu požiūriais.

Tikslinè nacionalinès kultūros vertybèmis ir vyraujančia politine ideologija paremto meno finansavimo programa, skirta unikaliam kultūros artefaktui (Latvijos valstybės šimtmečio sukakčiai), kino režisierių nèra suvokiama kaip kūrybinių filmų idejų pasirinkimo grèsmè. Vis dèlto tolesnių diskusijų ir tyrimų klausimas išlieka: ar (ir kokiomis sąlygomis) sistemingas panašių finansavimo instrumentų naudojimas gali skatinti rizikas socialinio lauko barjerams atsirasti ir kultūros srities įvairovei riboti.

Raktažodžiai: kūrybiškumo sociologija, sisteminis požiūris ị kūrybiškumą, kūrybinis procesas, kino meno kūrybinių idejų raida, kūrybinès kino režisierių idèjos 